\title{
ON THE SHORE
}

\section{Life Inside a Palisade Enclosure and Cultural Change during the Middle Neolithic B in Southern Scandinavia}

\author{
Kristian Brink, \\ Ingela Kishonti \& \\ Ola Magnell
}

\begin{abstract}
In 2006 a palisade enclosure dated to the late Middle Neolithic was excavated at Bunkeflostrand, Malmö, Sweden. The excavation of pits and wells containing flints, animal bones and pottery revealed a wide range of activities at the site, which is exceptional in comparison with most other palisade enclosures of southern Scandinavia. Palisade enclosures have emerged as places of great significance to our understanding of cultural relations traditionally associated with the transition from the Funnel Beaker culture to the Battle Axe culture. The results of the excavation at Bunkeflostrand and other palisade enclosures in the region can be used to understand social relations and cultural change in the Middle Neolithic in southern Scandinavia.
\end{abstract}

Key words: palisade enclosures, fishing, cultural transition, social relations, Middle Neolithic

\section{INTRODUCTION}

A drive south along the coast from Malmö through Limhamn and Bunkeflostrand will more or less take you along the stretch of the Järavallen beach ridge, which once marked the border between land and sea. When reaching Strandhem you will see newly built houses, representing a small proportion of the intense expansion of the city of Malmö during the last decade. Excavations here revealed the remains of a Middle Neolithic palisade enclosure, the fourth in the Malmö area (Brink et. al. 2008) (Figs. I, 2).

This article deals with the palisade enclosure at Bunkeflostrand and life there during the early part of the late Middle Neolithic (early Middle Neolithic B, 2800-2500 BC). The article also discusses aspects of 


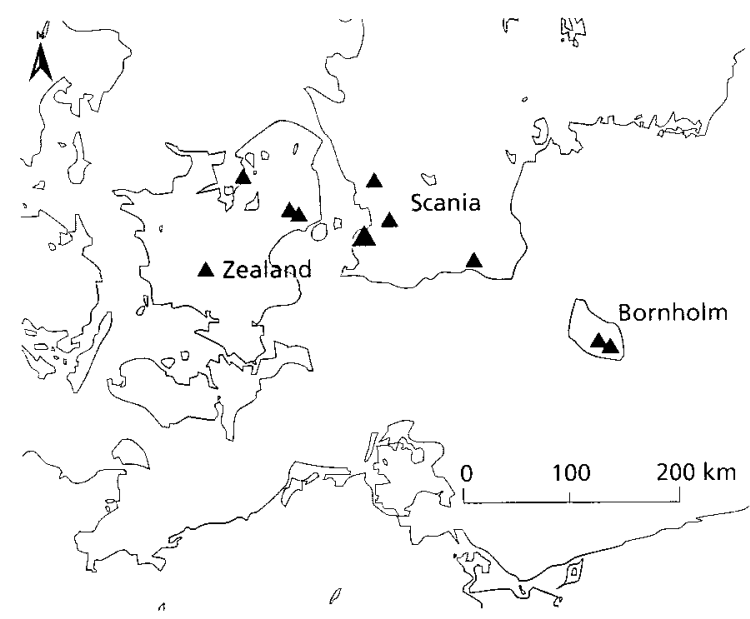

Fig. I. Southern Scandinavia - the area of the palisade enclosures of the late Middle Neolithic A and early Middle Neolithic B discussed in this article. See Fig. 2 for a detailed map of the Malmö area (large triangle).

the role of palisade enclosures locally in the Malmö area, and regionally in southern Scandinavia, during a period that is traditionally seen as a time of major cultural change.

The palisade enclosures of Scania and eastern Denmark are a fairly late phenomenon in Scandinavian archaeology and were first discovered in the late i980s (Svensson I99I). Since then several others have been documented (Fig. I). They have been characterized as the second generation of Neolithic enclosures, the first generation being the well-known Sarup enclosures of the late Early Neolithic and early Middle Neolithic, mainly found in Denmark. The function of these enclosed sites has been widely discussed. The older Sarup enclosures have been interpreted as sites of importance in the elaborate death rituals of local communities surrounding these sites (Andersen I 997). Archaeological remains from inside the younger, second generation of palisade enclosures are often scarce except for the traces of the palisades themselves. This has also made them more difficult to interpret in terms of general societal importance and use. As a whole there are both similarities and differences between these sites, indicating varied use at a local level. The palisade enclosure at Bunkeflostrand stands out from several other enclosures of this period through the rich and varied archaeological evidence in the form of features with finds of animal bones, flints and pottery. This has given a unique possibility to discuss the use of this site as well as the general importance of these sites in a south Scandinavian perspective.

The transition from the Funnel Beaker culture to the Battle Axe culture is a classic issue in Scandinavian archaeological debate. Immigra- 
$\hat{A}$

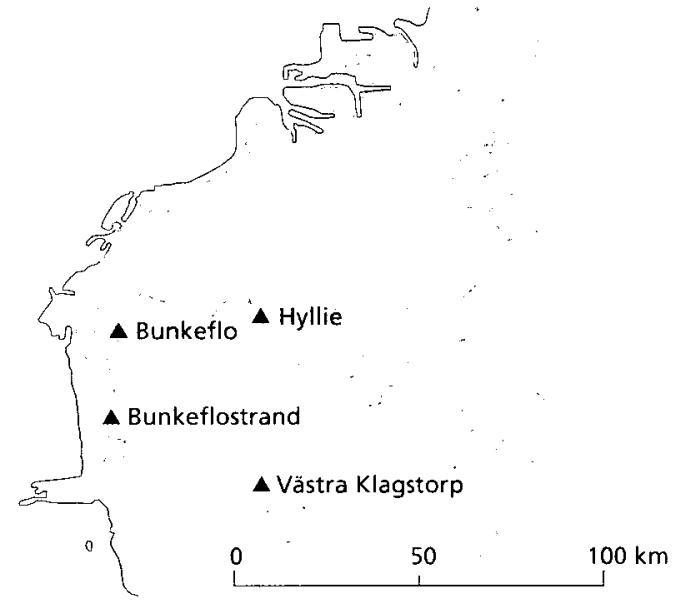

Fig. 2. The Malmö area with the location of the palisade enclosures indicated. Västra Klagstorp is the oldest, dated to the Middle Neolithic A.

tion or internal change, rapid or slow transition were major questions in this debate during the entire twentieth century, and they continue to be important (see e.g. Malmer I962; 2002; Kristiansen I991; Damm I993). The excavations of the palisade enclosures in the Malmö area, including Bunkeflostrand, have contributed valuable information to the discussion on Middle Neolithic cultural change in southern Scandinavia. Relating evidence from the palisade enclosures to other archaeological remains from the region can shed new light on the problem of how this change occurred.

\section{ON THE INSIDE}

\section{The enclosure}

The excavation site at Bunkeflostrand is part of a large, flat area of cultivated land and grassland. An extensive wetland once lay east of the site but is now drained. The site lies on the coast, unprotected from the prevailing winds coming in from the west across Denmark and the strait of Öresund. These winds, along with the heavy rains they brought, were clearly felt by all archaeologists involved in the excavation during the autumn and early winter of 2006. Starting in the end of October, it rained almost every day and the site became extremely muddy. In the flat area the water stayed where it fell, having no way off the surface. The water mixed with the clayey subsoil and formed a muddy carpet, inches deep, which covered most of the trench. It was under these conditions that the remains of the palisade enclosure were investigated. 
The enclosure had an irregular, rounded shape and a maximum extension of approximately $240 \times 300 \mathrm{~m}$ (Fig. 3). The inside area covered about 5.5 ha. The size makes it the largest of the three investigated contemporaneous enclosures in the Malmö area (Fig. 2). The preservation of postholes and ditches enclosing the inner area varied. The remains in the western part of the enclosure were well preserved, while the slightly higher eastern part was much more disturbed and difficult to detect due to the effects of modern cultivation. There was no convincing evidence of different phases in the construction. The enclosure has mainly had three parallel rows of posts, placed in single postholes. Ditches had been dug, however, before digging the individual postholes. Poor preservation made it impossible to detect post markings, but the general size of the postholes suggests that the construction was similar to Hyllie, where markings showed that the posts had had diameters between 0.20 and $0.40 \mathrm{~m}$ (Brink \& Hydén 2006: I 24). The western part of the enclosure was made up of three single and double rows of postholes that ran from the western edge of the main enclosure and out towards the former shoreline, perhaps with the old beach ridge as its western boundary. Between this outer room and the main enclosure there was only one row of postholes. The enclosure's extension to the north is somewhat uncertain since large parts of it lie outside the excavated area. Three entrances into the enclosure have been identified, as well as one entrance leading from the western outer room by the sea into the main area (Fig. 3). It is possible that more entrances have existed, but this cannot be verified due to the poor preservation of the enclosure.

\section{The site and its history}

The site contained archaeological remains that revealed a long history of use, ranging from the Mesolithic to historic times. Mesolithic evidence was sparse, represented only by a few flints, while the Early Neolithic phase was represented by a small number of pits and features interpreted as hut remains. Three graves from the Roman Iron Age and the remains of a building from historic time were the only archaeological evidence of use of the site after the Neolithic. The intense phase of use started with the Middle Neolithic palisade enclosure and the many pits and wells within it (Figs. 3, 4). During excavation we considered the features and the finds as the result of a relatively short activity phase clearly related to the enclosure. Features were similar in form, and finds in them indicated activities of a uniform character. In 


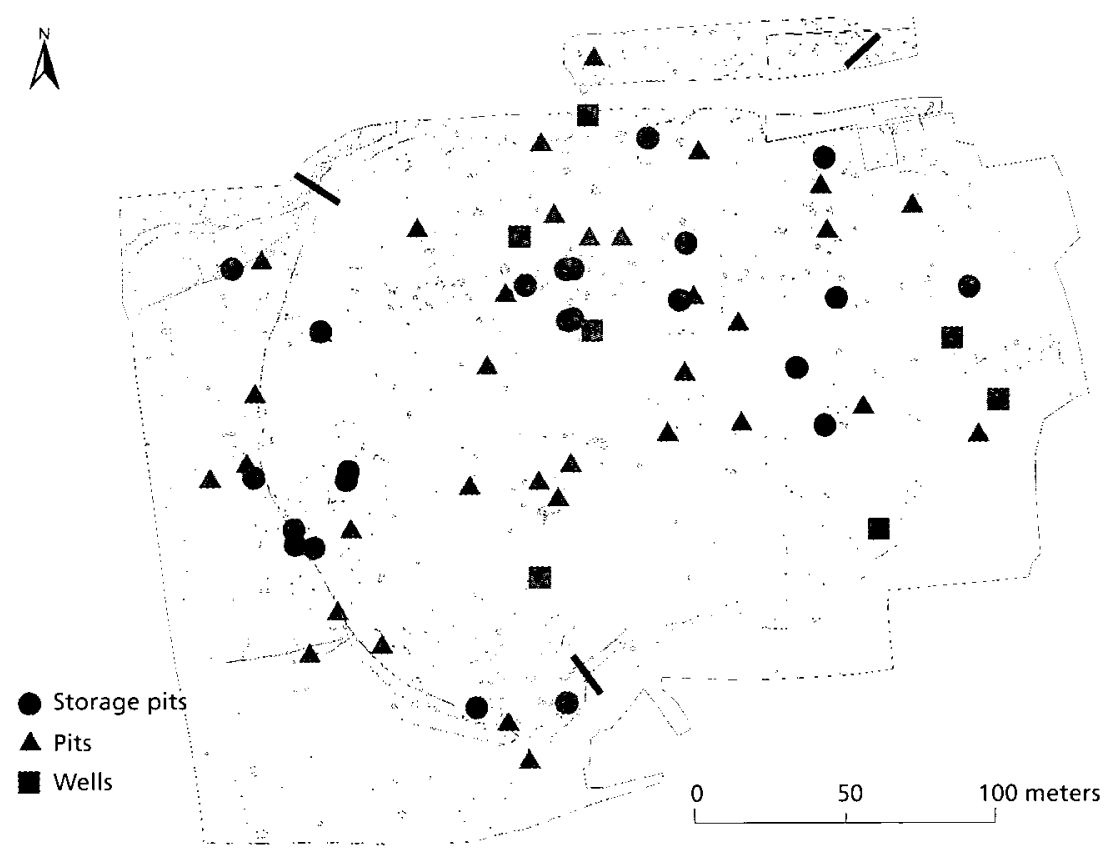

Fig. 3 . The palisade enclosure and features on the inside. Features indicated by symbols have been dated to the Middle Neolithic B. Thick lines indicate entrances leading into the enclosure.

total only twelve small pieces of decorated late Middle Neolithic pottery were found (Fig. 5). Cord ornamentation placed them within the Battle Axe culture, and the overall dating of the site suggested that they could belong to the A or B group, that is, to either of the two earliest periods of this culture (Malmer 2002:133ff). The fragments of flint axes found on the site were almost entirely of the thick-butted type, some hollow-edged, which on a general level confirms that activities should be dated to the Middle Neolithic (Karsten 1994:63). Overall the distribution of features correlates spatially to the enclosed area, and the same pattern is seen when studying the flint material found in the topsoil (topsoil from every to $\mathrm{m}$ within the area has been machine washed and sieved).

However, the impression of a chronologically limited phase of activities is not entirely supported by the ${ }^{14} \mathrm{C}$ dates from the site, even if the majority of the radiocarbon dates of pits indicate they were contemporaneous with the enclosure (Fig. 4). A study of the ${ }^{14} \mathrm{C}$ dates shows that activities took place in the Middle Neolithic B and in the early Late Neolithic, though decreasing in intensity towards the later period. It is not likely that the palisade enclosure had been standing there the 
Atmospheric data from Reimer et al (2004); OxCal v3.10 Bronk Ramsey (2005); cub r:5 sd:12 prob usp [chron]

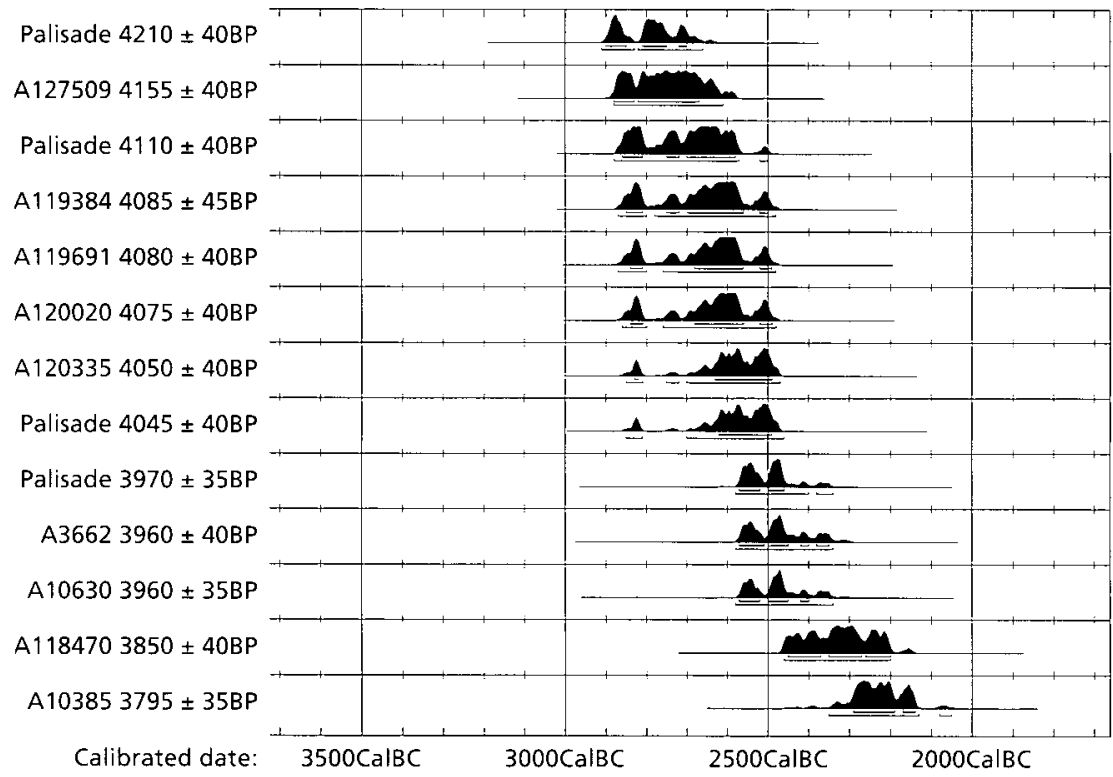

Fig. 4. Radiocarbon results indicating Middle and Late Neolithic activities (all results from the site are not included here).

entire time. Calculations made in connection with the excavation of the Hyllie enclosure show that somewhere between 60 and $\mathrm{I} 20$ years is the maximum lifetime for this type of construction if not repaired (Brink 2004; Brink \& Hydén 2006:I24). It may, of course, have been destroyed long before it reached that age. Radiocarbon dates do not pinpoint an exact time for when the palisade was in use. The ${ }^{\mathrm{r}+} \mathrm{C}$ dates indicate that it was built and used during the early part of the Middle Neolithic B, c. $2800-2500$ BC (Fig. 4). It is this phase in the history of the site that will be the focus of discussion here. Although of a similar character, activities of the late Middle Neolithic B and early Late Neolithic will not be considered here (see Brink 2009 for a discussion on this period).

\section{Pits and wells and what went on around them}

Features and finds from inside the palisade enclosure revealed intense activities, which so far have not been seen at any of the other investigated enclosures in the Malmö area. The features consist of wells and storage pits and also a large number of pits that have not been possible to assign to specific functions (Fig. 3). The features contained finds 
of flint, pottery, animal bones including tools, and macrofossils (hazelnut shells and grains) (Fig. 5). Features A I I 9384 , A I 1969 I, A I 20335 , AI 8470 and Aro3 85 (Fig. 4) contained cord-ornamented pottery. Shards with this type of ornament found in Ar20335 and AII 8470 had temper partly composed of chamotte, which is characteristic of pottery of the Battle Axe culture (Brorsson 2008). Finds in the topsoil were limited to flints. The conditions during excavation, with heavy rains, made it nearly impossible to retrieve finds from the features without water-sieving the fills. Water-sieving had been planned beforehand, but the circumstances forced a more intense and broad use of this method. This proved highly valuable in the interpretation and understanding of the site, especially since water-sieving is a prerequisite for recovering fragmented pieces of pottery and representative samples of fish bones.

The overall distribution of the features and the activities around them shows a pattern inside the main enclosure with a slight concentration to the north-western and western parts of the enclosure, while the eastern part had fewer features and finds in the topsoil (Fig. 3). The wells, all found inside the enclosure, show a fairly even distribution (Fig. 3). Notably there are no indications of any wells within the first $100 \mathrm{~m}$ of the presumed shoreline, and they are not found in areas less than $4 \mathrm{~m}$ above sea level. To dig wells in this area might have been too close to the sea, with incoming saltwater as a result. The wells functioned as water reservoirs for people and livestock, and in some cases seem to have been placed at a distance from the more intensely used areas.

Storage pits are a group of features that showed similarities in construction and often in finds and fills. They consisted of more or less round pits, 0.5 to $0.6 \mathrm{~m}$ deep, with fairly straight, steep walls and flat or slightly bowl-shaped bottoms. The storage pits were found in most parts within the enclosed area. A slightly higher occurrence was, however, seen in the northern half and along the single row of postholes separating the large inner area from the space open towards the sea. The function of these pits might have varied in detail, but the general interpretation is that these easily accessed pits have been used for storage. They were too small to have served as work pits, lacked the general elements of wells, showed no sign of direct fire-related activities, and seem to have been filled in with soil and refuse once they were no longer in use. 

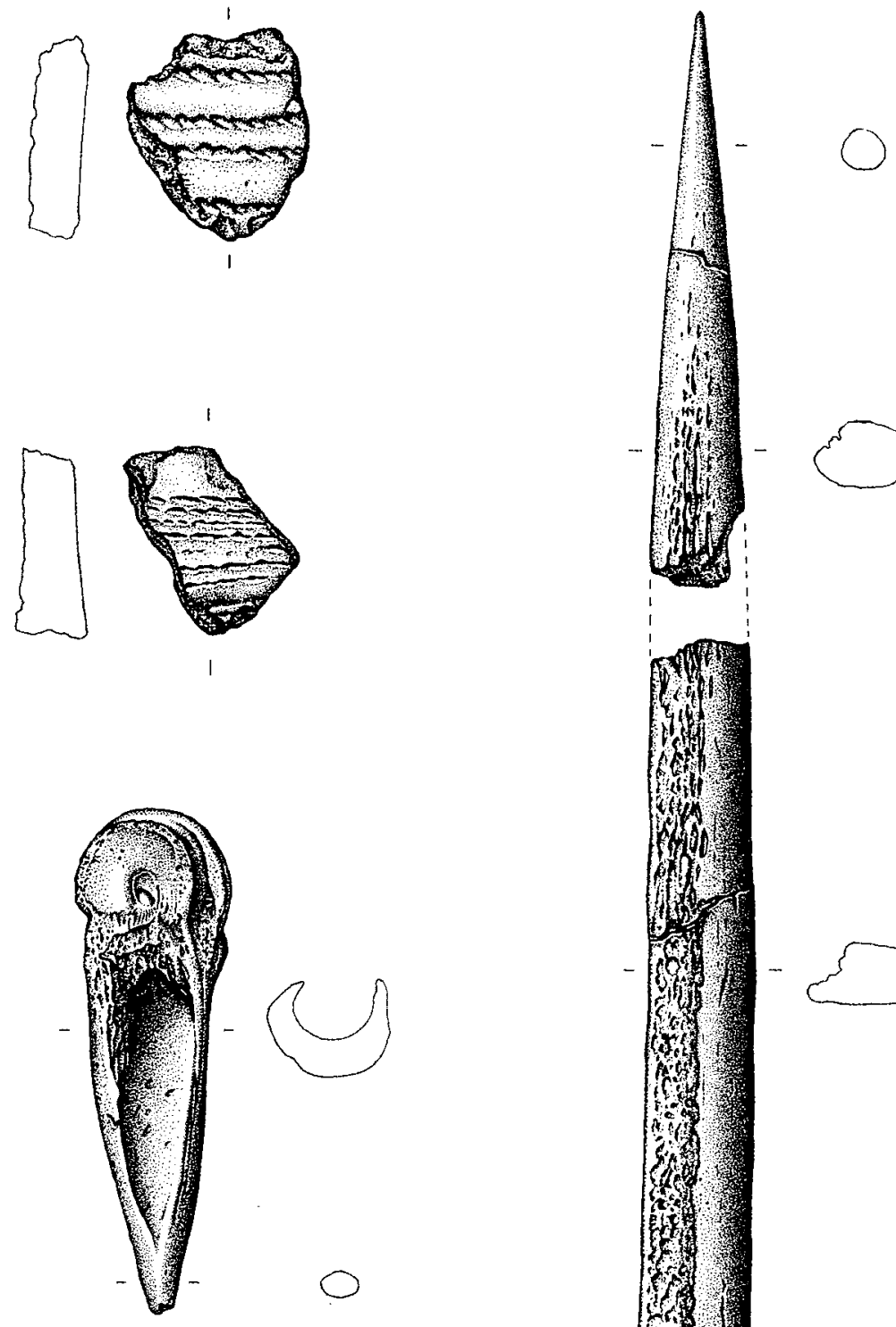

Fig. 5. Cord-ornamented pottery from storage pits A I I 969 (top left) and A I 20335 (this shard is partly tempered with chamotte) and pointed bone tools from a well, A I19384. Scale I:I. Drawings by Björn Nilsson. 
Finds in the features and in the topsoil reveal activities in the area around the features. Finds and features can together generally be described as the result of settlement activities at the site in the sense that they represent longer periods of stay. Hearths were almost non-existent and only occurred at a couple of places. Most hearths can be assumed to have disappeared due to modern agricultural activities in the area, but the rather large amounts of burnt flint, bone and charcoal in both the pits and the topsoil show that hearths were an important part of the site.

The flint material from the topsoil is of the same kind as that found in the features. Axe fragments, scrapers, burnt flint and flakes, of which several are from the production of four-sided axes or chisels, were found in both contexts. As mentioned, the spread of finds in the topsoil indicates activities in areas with the largest concentrations of storage pits and other pits. Most of the find material in the features is considered to be the result of secondary depositions and is not linked to the primary function of the features. The bones and pottery were very fragmented, which suggests that they had been trampled on during activities close to the features and that they had ended up in the features when the latter were filled in after use. There were, however, also a number of pits that contained deposits of animal bones, antler and flint (waste from the production of axes or chisels), and these have been interpreted as the result of ritual activities.

One category of finds, the animal bones, tells of specific activities that are seldom possible to discuss in detail through archaeologically retrieved evidence from Neolithic sites in southern Scandinavia. The animal bones are not only among the largest assemblages from the period in this region but are also of great importance to understanding the role of the site in local society.

\section{Fishing}

Animal bones recovered from pits and wells inside the enclosure present a unique opportunity to understand activities at the site. Few animal bones have been found during earlier excavations of palisade enclosures in the region. The large material of fish bones, making up $93 \%$ of the total NISP (number of identified specimens), indicates the importance of fishing at the site (Tables I, 2). Fish bones were found in several wells, storage pits and other pits spread over most of the enclosed area. This spatially widespread occurrence of fish bones underlines the 
importance of fishing and processing of fish. As a comparison, bones from codfishes (gadids) were found in 22 features, while cattle bones were found in only ten (Tables $\mathrm{I}, 2$ ).

\begin{tabular}{lcc}
\hline & NISP & $\begin{array}{c}\text { number of } \\
\text { features }\end{array}$ \\
\hline codfish (Gadidae) & 3423 & 22 \\
cod (Gadus morhua) & 858 & 12 \\
haddock (Merlanogrammus aeglefinus) & 3 & 2 \\
saithe/pollack (Pollachius) & 13 & 2 \\
herring (Clupea harengus) & 89 & 5 \\
flounder (Pleuronectidae) & 93 & 10 \\
garfish (Belone belone) & 15 & 4 \\
spurdog (Squalus acanthias) & 12 & 4 \\
perch (Perca fluviatilis) & 5 & 2 \\
eel (Anguilla anguilla) & 2 & 2 \\
salmonids (Salmonidae) & 1 & 1 \\
pike (Esox lucius) & 1 & 1 \\
\hline
\end{tabular}

Table I. Fish bones from Bunkeflostrand dated to the Middle Neolithic B. NISP=Number of Identified Specimens.

Gadids are clearly the most common type of fish in the material, with $94 \%$ NISP of the fish. Almost all bones (99\%) from gadids come from cod (Gadus morhua). This is expected since cod more or less dominates fish bone assemblages from southern Öresund dating from the Late Mesolithic to the Middle Ages (Cardell 2005; Nilsson 2006:44ff; Magnell 2007). After cod, herring and flounder are the most frequently occurring fishes in the material (Table I). Bones of cod have generally greater chance of being preserved than several other species, such as herring with smaller, more fragile and fatty bones (Enghoff I 987 ; Mésez \& Bartosiewicz 1994). Due to taphonomic factors it is likely that especially herring was more important at Bunkeflostrand than the fish bone sample indicates.

Cod fishing must have been of great significance at the site. One way to illustrate this is to calculate the estimated killed-population that fish bones in single features represent based on algorithms of counts of left- and right-side elements and apparent pairs (Wild \& Nichol I983). In one pit, AI 20020 , in the northwest part of the enclosure, a total of I 076 bone fragments of gadids were recovered representing a minimal number of 36 individuals. The calculation of estimated killed-popu- 
lation indicates that the bones could represent as many as 684 fishes. These statistical methods are unreliable and subjective since they are dependent on the number of pairs one is able to match ( $\mathrm{O}^{\prime}$ Connor 2000). However, in this case it is not the exact amount that is of interest, but rather the possibility to show that the bones from a single feature may represent catches of several hundred fishes. If one further considers that only the fish bones that ended up in the deeper pits actually became preserved, it is obvious that huge amounts of cod must have been brought to the site.

The anatomical distribution of bones of codfish, which shows a high frequency of bones from the head and vertebrae, indicates that whole fishes were brought to the site, but bones from the shoulder girdle are remarkably few. The low frequency of bones from the shoulder girdle, such as cleithrum, can hardly be explained by taphonomic factors, since this is actually one of the largest and hardest bones in cod and it is not especially sensitive to sedimentary abrasion and trampling $(\mathrm{Ni}-$ cholson I992a; I992b). The low frequency of bones from the shoulder girdle could be explained if the sides of the fish with bones from this area were cut from the head and vertebral column along with fillets to be dried. It thus seems that large amounts of fish were caught in the waters outside Bunkeflostrand and brought to the site for processing into dried fish, which was then distributed and consumed at other sites. We will return to this further on.

\section{Antler and wild game}

Another special aspect of the animal bones from Bunkeflostrand is the amount of antler of red deer. Antler was found in twelve different pits from the Middle Neolithic B. Different parts have been found, in some cases only small fragments, but also tines, beams, crowns as well as more or less complete antlers. Antler fragments usually occur on Neolithic settlements in southern Scandinavia, but rarely more often than bones of cattle as at Bunkeflostrand. One site in the region where parts of antlers have been frequently found is Ängdala, located just outside Malmö and known for its flint mines. The antlers have most likely been used for mining, and some finds of whole antler picks have been made, although most of the antler from the flint mines consists of parts of beams and crowns (Rudebeck r.986). 


\begin{tabular}{lcc}
\hline & NISP & $\begin{array}{c}\text { number of } \\
\text { features }\end{array}$ \\
\hline cattle (Bos taurus) & 20 & 10 \\
sheep/goat (Ovis/Capra) & 25 & 11 \\
pig (Sus scrofa/domesticus) & 12 & 5 \\
dog (Canis familiaris) & 14 & 5 \\
roe deer (Capreolus Capreolus) & 32 & 5 \\
red deer (Cervus elaphus) & 14 & 8 \\
red deer - antler & 18 & 12 \\
red fox (Vulpes vulpes) & 3 & 2 \\
weasel/stoat (Mustla erminea/nivalis & 1 & 1 \\
squirrel (Sciurus vulgaris) & 1 & 1 \\
human (Homo sapiens) & 1 & 1 \\
\hline
\end{tabular}

Table 2. Osteological remains of mammals from Bunkeflostrand dated to the Middle Neolithic B. NISP=Number of Identified Specimens.

The antler parts from Bunkeflostrand can be associated with digging and possibly the construction of the enclosure. Picks were, for example, probably used when digging the narrow ditches before putting up the posts. Most of the animal bones come from features within the enclosed area, while actually half of the features with antler are situated along the stretch of the actual palisades. A pick or an axe socket of antler was also found at the palisade enclosure at Hyllie, and other examples are known from several Neolithic enclosures across Europe (Brink \& Hydén 2006:67; Andersen 1997:284).

Animal bones from Middle and Late Neolithic sites in Scania and Denmark usually come from domestic animals, and only few bones of wild game are found (less than $7 \%$ of NISP) (Nyegaard I98 5 ; Larsson I992a; Sarnäs \& Nord Paulsson 200I; Nilsson 2006). It is therefore remarkable that $4 \mathrm{I} \%$ of the identified bones of mammals from Bunkeflostrand come from wild animals (Table 2). Note that antlers have been excluded from the quantification and that bones of pigs have been counted as domestic, even though it is highly possible that some of the pig bones actually come from wild boar. Red deer and roe deer are the most common wild game, but there are also a few bones of smaller fur-bearing animals such as squirrel, red fox and weasel/stoat (Table 2). At the palisade enclosure at Hyllie bones of wild animals ( I $2 \%$ of NISP) were also more frequent than on settlements (Jonsson 2003). It thus seems that hunting and consumption of wild animals can be associated with the palisade enclosure at Bunkeflostrand, which distinguishes the site from ordinary settlements. 


\section{Seasonality}

Seasonal indicators from the animal bones show that the site may have been used during a relatively short period of the year (Fig. 6). Seasonal indicators from the site are few, and some are rather uncertain, but all point towards use of the site during the summer and early autumn. As always with analysis of seasonality it is important to consider that the animal bones may reflect seasonality of certain activities, but that the site can also have been used during other parts of the year for other purposes. However, fishing and slaughter of pigs and sheep seem to primarily have occurred during summer and early autumn.

\begin{tabular}{|l|l|l|l|}
\hline \multicolumn{1}{|c|}{ Mar Apr May Jun Jul Aug Sep Oct } & Nov Dec Jan Feb \\
\hline garfish (Belone belone) & & & \\
- occurrence in Öresund \\
spurdog (Squalus acanthias) \\
- occurence in Öresund \\
herring (Clupea harengus) \\
- spawn in Öresund \\
pig (Sus domesticus) \\
- juvenile (5-6 mon) \\
sheep (Ovis aries) \\
- juvenile 6-9 mon \\
red deer (Cervus elaphus) \\
- unshed antler
\end{tabular}

Fig. 6. Seasonality at Bunkeflostrand based on animal bones. Black indicates the shortest period of the year the site could have been used. The seasonality analysis is based on the assumption that the spawning and occurrence of different species of fish in Oresund during the Neolithic was similar to the situation today. This also goes for the breeding of pigs and sheep in the spring.

Activities at the site took place during a long enough period of the year as to necessitate the digging of wells for fresh-water supply. Investing time and energy in digging wells and also storage pits indicates that people stayed longer than a few days or even weeks at a time. The site was probably occupied for several months of the year as indicated in Fig. 6. The filling in of individual storage pits and wells may have been done after each season ended. Seasonal occupation is perhaps also revealed through spatial tendencies in the spread of features within the enclosure (Fig. 3). Small clusters of features can be seen in some parts, perhaps representing the digging of storage pits and other pits in a single season.

If people lived at the site some sort of shelter must have been re- 
quired. Remains of substantial post-built houses were not found within the enclosed area, which may accord with the fact that occupation of the site was limited to a few months per year. Post-built two-aisled houses from this period have been documented at other sites in the Malmö area, indicating that this was not an uncommon type of building on settlements (Brink 2009). It has to be noted that the excavation conditions were problematic due to heavy rains, which clearly decreased the possibility of finding such remains at the site. At least four possible hut structures were identified, but they have been dated to the Early Neolithic just as have several other hut remains of this type from the Malmö area (Hadevik 2009). However, it may have been this simpler type of building that was used during the late Middle Neolithic at the palisade enclosure in Bunkeflostrand.

Fish bones indicate intense fishing during part of the year, which suggests that it had some importance for diet during the time period. However, analyses of stabile isotopes, $\delta{ }^{13} \mathrm{C}$, of human bones from the Malmö area dating from the Middle Neolithic to the Early Bronze Age indicates that the diet in the area was mainly based on food from land and not from the sea. Only one human bone was found at Bunkeflostrand, but unfortunately the poor preservation of collagen in the bone made analysis of stabile isotopes problematic. However, analysis of $\delta$ ${ }^{13} \mathrm{C}$ of two skeletons from graves of the Battle Axe culture in the area, slightly younger than the palisade enclosures, indicates a mainly terrestrial diet (Magnell 2007). The fish bones from Bunkeflostrand indicate intense consumption and processing of fish at the site but also that it probably was limited to a shorter period, while stabile isotopes show the diet over a longer period of time.

In conclusion, the evidence seems to support that fishing at Bunkeflostrand, and indeed during the whole of the late Middle Neolithic, was a seasonal activity that was not performed by a specialised local fishing community but rather by gatherings of larger groups of people from settlements in the surrounding area. Dried fish was brought to settlements further inland. Their main source of food, however, did not come from the sea. Hunting also seems to have been of greater importance at the site than is generally known from settlements. It is, however, time to look outside the palisade to get a broader understanding of its role and its importance to people and society in the early third millennium BC. 


\section{ON THE OUTSIDE}

\section{Culture and chronology in a multi-temporal world}

The palisade enclosure at Bunkeflostrand is just one of several similar sites in southern Scandinavia (Scania and eastern Denmark) (Svensson 2002; Nielsen 2004; Thörn 2007) (Figs. I, 2). These sites are in turn part of a long and geographically widespread European Neolithic phenomenon of enclosing space with stone, earth or wood (see e.g. Andersen I997; Gibson 2002; Nielsen 2004:28f). The south Scandinavian enclosures belong to a period of complex cultural relations, which is clearly manifested in the palisade enclosures themselves. The first to be discovered was the enclosure at Hyllie, Malmö, investigated in 1989 (Figs. 2, 7). Soon several others started to emerge throughout the region. One of the investigators of Hyllie, Mac Svensson, later named the palisade enclosures of this time the "second generation of enclosed sites" (Svensson 2002). The first generation is represented by the well-known causewayed enclosures, named after the famous and thoroughly investigated Sarup location (Andersen I 997).

The palisade enclosure at Hyllie was not only the first of its kind to be discovered. It was also considered special because of the few but culturally significant finds. One piece of pottery and one hollow-edged flint axe belonging to the Battle Axe culture were found in posthole fills. Radiocarbon dates confirmed the enclosure as belonging to the Middle Neolithic B (Svensson r 99I). This was all the more remarkable since the Battle Axe culture was, and still is, known primarily through its characteristic graves. Settlements are unusual, though their numbers are increasing. The palisade enclosure at Hyllie therefore emerged as an unexpected and also enormous construction built by people who previously had been seen as erecting only small and simple houses, if any at all. The Hyllie enclosure was then followed by the enclosures at Bunkeflo, Dösjebro and Bunkeflostrand, which also contained material evidence pointing towards the Battle Axe culture. The palisade enclosure at Västra Klagstorp in Scania (Fig. 2), however, is dated to the Funnel Beaker culture through both the finds and the ${ }^{14} \mathrm{C}$ dates (Friman 2006). The palisade enclosures of eastern Denmark, on both Zealand and Bornholm, have so far also been attributed to the Funnel Beaker culture (Kaul et al. 2002; Giersing 2004).

Thus, the Neolithic palisade enclosures show a division into different cultural traditions: one connected to the Funnel Beaker culture 
and the other to the Battle Axe culture. They are also implicitly divided both in time and understanding in terms of social significance along the border of these Middle Neolithic cultures (Svensson 2002; Andersson 2004; Brink 2004; Nielsen 2004; Brink \& Hydén 2006; Thörn 2007). This division is, of course, based partly on the archaeological evidence at the investigated sites, but implicitly also on the notion of clearly separable Neolithic cultures of almost essential qualities. Palisade enclosures were built and used during the latest part of the Middle Neolithic $A$ and the early half of the Middle Neolithic B, from around 3 Ioo3000 BC to 2600-2500 BC (Brink 2009; see also Nielsen 2004:20 for a slightly different time frame). Radiocarbon dates from the Danish sites are equivalent to the dates of the Scanian sites attributed to the Battle Axe culture. The ${ }^{14} \mathrm{C}$ dates cannot be used to separate these sites of differing cultural traditions. Wiggles in the calibration curve cause large deviations in the ${ }^{14} \mathrm{C}$ dates of the period (Tauber 1986:204; Nielsen 2004:29; Skak-Nielsen 2006:276). This is clearly exemplified by the dates from the palisade enclosure at Bunkeflostrand (Fig. 4).

If we turn to the evidence outside the wooden walls of the palisade enclosures of Malmö the problem of culture becomes evident. Evidence in this area does not indicate Battle Axe culture sites surrounding the enclosures (Brink 2009). Using the classic archaeological cultural terms, what we have are rather remains of material culture that should be seen as being left by people of the late Funnel Beaker culture. This is in accordance with the general evidence from Scania during this period (Edenmo et al. 1997). Turning to the culturally most unproblematic evidence of Battle Axe culture presence: the well-known burials also support a general picture of cultural relations as not being straightforward. There are, as of now, no convincing ${ }^{14} \mathrm{C}$ dates from Battle Axe burials from before $2600-2500 \mathrm{BC}$ in Scania. In this respect the Battle Axe culture, viewed as a burial culture, can at present be firmly dated to the late Middle Neolithic B and the early Late Neolithic (Brink 2009). Thus, the general evidence so far supports the Battle Axe burials as being of a time when the large palisade enclosures were no longer built or even used in the region.

The general difficulty of separating cultures of this period is reflected in the slightly varied chronological frameworks used to set the boundary between the two periods in question - the Middle Neolithic A and the Middle Neolithic B. This varies somewhat among researchers, ranging from 2800 to $2700 \mathrm{BC}$ (Andersson 2004; Edenmo et al. 1997). The 
boundary of archaeologically constructed periods, related to the archaeological record, has been used as a tool in the search for cultural and societal change. Regardless of the boundary chosen, this period has been interpreted as one in which several different cultural and ethnic groups co-existed for some time in the region (Larsson I992b; Andersson 2004; Edenmo et al. 1997; Larsson 2006). The problem of culture and chronology in relation to the palisade enclosures is, as said earlier, complicated. However, a view on the cultural and chronological relations of this period must be presented before an attempt can be made to understand the role and importance of these sites in a south Scandinavian perspective. It must be considered all the more important since these sites can help to shed light on cultural and social relations of the period and thereby contribute to an understanding of societal change in a long-term perspective.

Some of the material evidence from the palisade enclosures in Scania, in particular the small shards of Battle Axe pottery and flint axes, have been brought forward and given supremacy in the interpretation of the cultural affiliation of these sites. The enclosures themselves, as part of a long tradition dating back to the late Early Neolithic Sarup enclosures, have not been given the same attention as material evidence of cultural significance. Looking at the evidence as a whole reveals what can be called an "overlap" of cultural traditions in the Scanian palisade enclosures. The material evidence should therefore be interpreted and understood as part of a multi-temporal world (Olivier r999). Just like the people of the past, we are surrounded by material culture of different times - from small objects to the totality of landscapes. People, as individuals or as part of groups, are constantly negotiating social relations. The latter are produced and reproduced as well as changed, through active choices or through unintended outcomes of these choices. Material culture forms an active and important part in this negotiation (Barrett 200I). This includes architecture in the form of different types of buildings (Parker Pearson \& Richards I994). Viewing the palisade enclosures as part of a multi-temporal world is in this case based on the notion that the cultural change from the Funnel Beaker to the Battle Axe culture was a protracted process and not a single event. The change should not be understood as a change from one clearly defined (material) culture to another. It is part of a continuum of negotiated and renegotiated social and cultural relations in history. This notion is simple in itself but very difficult to get a firm grip on through 
the archaeological evidence. Nevertheless, the following discussion of the role of the palisade enclosures in society will follow along the trail of this simple but archaeologically evasive notion.

\section{Enclosures and society in the early third millennium $B C$}

Through their steady increase in number, the palisade enclosures have emerged as places of general importance to life in the early third millennium BC, both in the Malmö area and in other parts of southern Scandinavia. The palisade enclosures' general role in society has been summarized by Svensson: "We believe that the sacred and profane were strongly integrated at the palisaded enclosures and that these places acted as central places to enable local communities to foster communication and contact with the physical, metaphysical, and spiritual worlds. They were places for assemblies, places to hold passage rites, to honour the dead and contact the gods, places for exchange and competition with others" (Svensson 2004:246). The quotation clearly demonstrates that the palisade enclosures of this time are seen as places of diverse and central importance to society. The almost all-inclusive interpretation is, of course, also a result of the very limited material evidence of activities from many of these sites. This separates them on a general level from their older relatives in the south Scandinavian enclosing tradition - the Sarup causewayed enclosures.

The Sarup causewayed enclosures of the late Early Neolithic and early Middle Neolithic have been thoroughly studied by Niels H. Andersen (I.997). Andersen's assessment of the function of these sites stands in rather sharp contrast to Svensson's characterization of the younger palisade enclosures. Human bones at the site are seen as part of complex death rituals that include the megaliths of the surrounding landscape. The regular architectural layout of the Sarup enclosures with its system-ditches and palisades is interpreted as a reflection of the social organization of society. The regularity reflects single units of small family groups in the area around the enclosure, each family group represented by their own section. The Sarup site thus becomes a "village of the dead" for the entire community sharing this common place. Later, towards the middle and end of the Middle Neolithic A, the use of the Sarup site changes as they turn into large settlements, reflecting a change in society.

The late fourth and early third millennia represent a period of change and negotiation of social relations across southern Scandinavia (Damm 
I99 I; Larsson I992b; Andersson 2004; Svensson 2004; Björhem \& Magnusson Staaf 2006; Larsson 2006; Rostoványi 2007). People are thought to have lived in larger groups in parts of southern Scandinavia from the middle of the Middle Neolithic A and onwards until the very end of the period when more diversity can be seen in terms of the size of sites. The group was considered more important than the individual, but local communities were nevertheless led by the elite who had authoritative power to control sacred, economic and social aspects of life (Damm I 99 I:70ff; Rostoványi 2007:I30). In recent research, late Funnel Beaker society in western Scania has been characterized as a period when the power of these traditional leaders was questioned by groups of people influenced by new ideas. The power of these leaders is said to have rested on ancestral veneration, rituals being performed at the old megalithic tombs. This was now contested and families broke out of this social strain, forming social groups whose material culture we recognize as the Battle Axe culture of the Middle Neolithic B (Andersson 2004: $186 \mathrm{ff}$; see Larsson I 992b for a similar interpretation in southern Scania). Rituals at the old megaliths are characterized as being more private during the Middle Neolithic B, that is, they were no longer performed as rituals involving large groups of people led by the old leaders of the community. This followed a general change towards greater emphasis on personal skills and the possibilities for individuals and individual families to change their social position (Andersson 2004: I98ff). In eastern Denmark access to the old megalithic tombs opened up, making it possible for more people to bury their dead and of course to be buried themselves in these tombs (Damm I991:72). This is suggested to have been a way of controlling social tension, of preventing radical social change of the kind that had swept across Jutland when the Single Grave culture changed society from the early third millennium and onwards. Of course, in spite of these attempts to deal with the new influences eastern Denmark and Scania were in the long run clearly affected by them. The palisade enclosures built in the region played an important part in this long-term process.

\section{Enclosed relations}

A few kilometres to the north and northeast of Bunkeflostrand as the crow flies are the large, investigated enclosures of Bunkeflo and Hyllie (Brink \& Hydén 2006; Thörn 2007) (Fig. 2). Were three large enclosures standing at the same time in the area? The evidence does not 
permit any certain conclusions. The enclosures show some similarities, foremost in size and shape, which speak in favor of at least some form of co-existence, perhaps not directly in physical form but at least as an idea in the minds of those who built, used and visited them. This is supported on a general level by the ${ }^{14} \mathrm{C}$ dates. In spite of their similarities the enclosures were also partly used in different ways, which shows that the idea of enclosing space in this way was not tied to strict uniform traditions in function or meaning. This is, for example, seen in the difference in activities at Bunkeflostrand and Hyllie, where the latter site lacks the abundance of features seen at Bunkeflostrand (see Brink 2004 for Hyllie) (Figs. 3, 7).

The palisade enclosures were not built as monuments intended to last for centuries (Andersson 2004:2 I4). As constructions they did not contain expectations of social or other importance beyond the builders' own lifetime or the lifetime of the wood used to build them. Aside from the enclosures of Bornholm there seems to be no clear evidence of different phases in these constructions. As a whole they are to be considered as single architectural units, planned, built and used in the form that is revealed through the patterns of the postholes (see Thörn 2007:87 for a different interpretation).

The enclosures were part of a landscape of diverse sites, where they served as places for larger communal activities during certain shorter or longer periods of time. This is perhaps most clearly seen at Bunkeflostrand through the evidence of seasonality and fishing (Brink 2009). The landscape of the Funnel Beaker culture in the Malmö area has been characterized as one of high local mobility where people had collective access to the different sites of the area (Björhem \& Magnusson Staaf 2006: I 2 Iff). We hold this to be true for the early Middle Neolithic B (Brink 2009) as well. The enclosures were places of diverse and open social relations, formed on the basis of local ideas, traditions and needs. They were probably accessible to a large part of the local community, as were the sites of the surrounding landscape as a whole. This may, of course, have been regulated at the level of when and how access to the enclosures was permitted by the leaders of the communities.

Interpretations of the enclosures of southern Scandinavia have largely focused on ritual aspects of life. This is partly a result of the archaeological evidence, which often consists of deposits of flint and animal bones in postholes or pits. Large amounts of burnt flint at several 


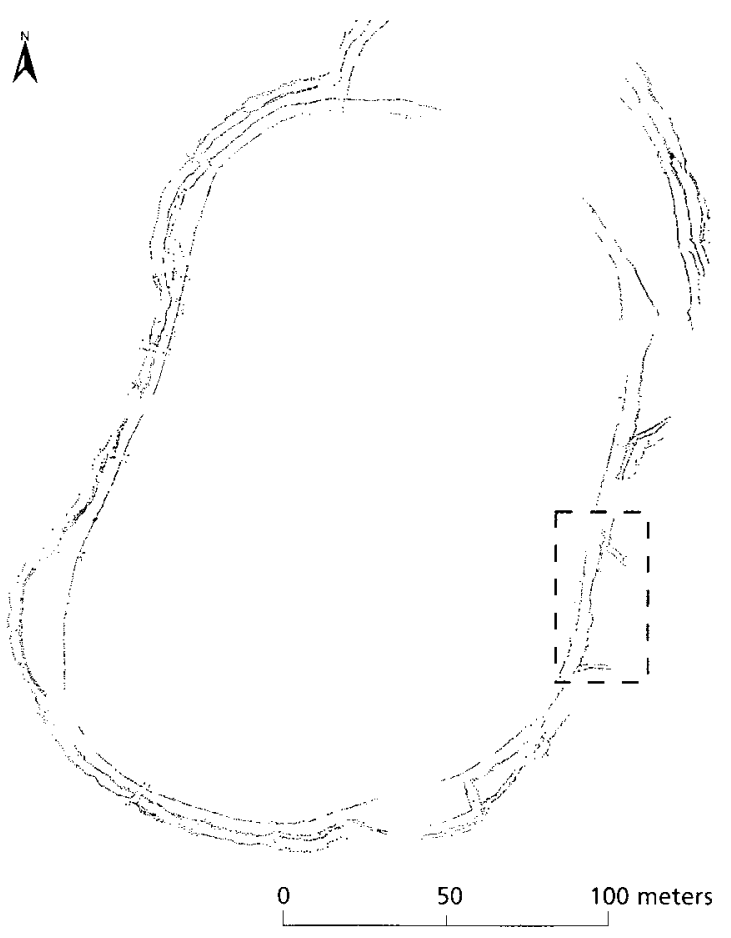

Fig. 7. The palisade enclosure at Hyllie. See detail in Fig. 8.

of these sites are also generally interpreted as a result of ritual activities, just as in several other Neolithic contexts (see e.g. Brink \& Hydén 2006; Nielsen 2004; Larsson 2004). Few other traces of activities have been documented apart from the flint-knapping areas outside the enclosure at Dösjebro in western Scania (Svensson 2002). The preference for ritual interpretations is, of course, also a result of the interpretation of the older Sarup causewayed enclosures and of the enigmatic buildings themselves, as their size and form do not seem to suggest a wholly practical function. Ritual can, however, not be separated from everyday life (Bradley 2005), as the evidence from Bunkeflostrand clearly shows. The characterization of the palisade enclosures on Bornholm as fortified settlements of ritual importance also recognizes this (Kaul et al. 2002; Nielsen 2004:28).

We suggest that changes within local societies were negotiated, expressed and materially manifested in the enclosures by groups of individuals cutting across the level of family and kin. Instead we can understand change and social negotiation as part of the process of forming social relations, which does not necessarily involve homogeneous 
family- or kin-based social entities that can be sorted out from one another as separate cultural groups in the same way as discussed in the previous section. That is, the change from what is termed the Funnel Beaker culture to the Battle Axe culture did not imply that homogeneous groups of family or kin all simultaneously changed their way of life and thinking in comparison to other such homogeneous entities. We propose that this can be archaeologically traced in the palisade enclosures - both in their form and in the way they were used.

Ritual deposits as well as the general evidence of everyday activities can be interpreted as expressions of social relations. Their meaning was of relevance within the enclosures, but also expressed relations stretching outside the boundaries of the palisades. The manufacture and distribution of flint axes are considered to have been of great importance at several of the sites (Svensson 2002). At Dösjebro, knapping-areas have been documented just outside of the palisades. Such areas have not been found at any other site. At other sites the evidence of axe production consists of large deposits of flakes in postholes and pits, as most clearly seen at Hyllie and Bunkeflostrand.

At the Hyllie enclosure a room of special importance has been identified (Figs. 7, 8). Around the entrance leading into this room, large amounts of flakes from the production of flint axes or chisels were found deposited in the postholes, including several burnt flakes. This room is here interpreted as marking the importance of flint working and the distribution of flint products at the site, but possibly also the importance and status of flint-knappers from the area. These people, who came from different parts of the local area, were able to manifest their special role at these sites. A similar manifestation can be proposed for the palisade enclosure at Dösjebro. This architecturally simpler enclosure consisting of a single $U$-shaped palisade had flint flakes from the production of axes or chisels deposited in postholes, primarily in the eastern part of the enclosure (Svensson et al. 200I:I $3 \mathrm{ff}$ ). Thus, manifestation of a similar kind as in Hyllie can be proposed, although this does not mean that a special room was built. Instead a special part of the one large space was singled out.

The interpretation of the enclosures as places of importance in the long-distance distribution of flint has been criticized. Flint-knapping areas and axes or flakes from axe production are suggested to be the result of building the enclosures. Axes and chisels were needed for this (Thörn 2007: I 40). The physical evidence in itself can, of course, not 


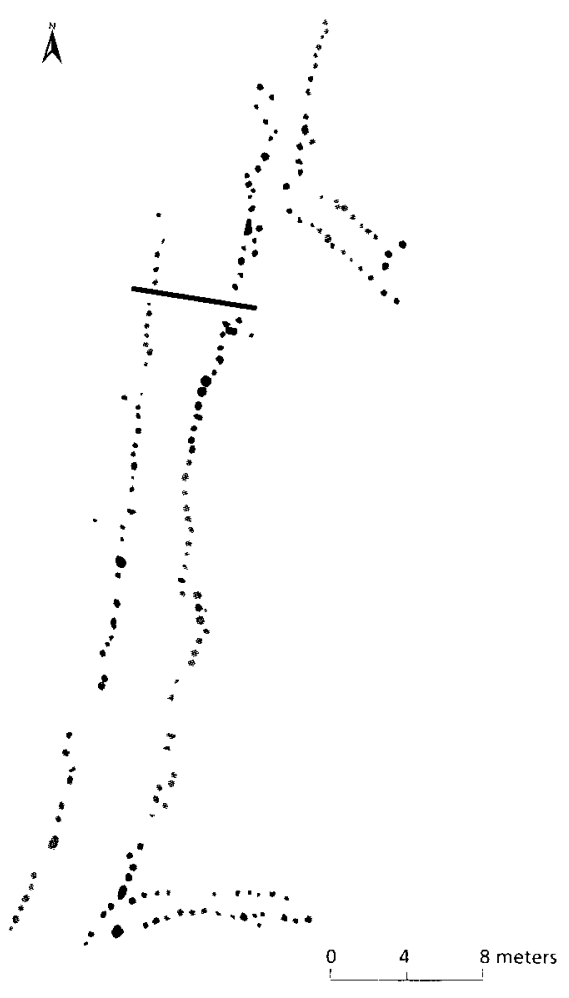

Fig. 8. Social space inside the Hyllie enclosure. Black indicates postholes containing large amounts of flint. They were concentrated around the entrance (thick line) into this part of the enclosure. Several flakes are waste from the production of axes or chisels.

be used for drawing sure conclusions. Tools for felling trees and for woodwork were definitely needed, both when the trees were cut down and at the actual building site. But it is also known that flint moved across large areas during the Scandinavian Neolithic (see e.g. Strömberg 1988; Svensson 2002:49; Lindholm et al. 2007:228). These longdistance contacts must have required organization at the local level. The palisade enclosures may very well have been places where this was carried out. Bunkeflostrand, for example, was a place of seasonal importance where activities of both local and regional importance took place. These activities seem to have occurred during a time of year well suited for long-distance travel, and therefore the enclosure was a place where outside visitors came in contact with the local community. This is, of course, also true for the enclosure at Bunkeflo, which is also situated close to the shore (Fig. 2). Perhaps the location of the Hyllie enclosure a bit further inland can be seen as a way of distancing it from direct contact with visitors from afar. Did visitors have to pass the coastbound enclosures before being given permission to continue? 
The palisade enclosures formed important sites for long-distance contacts across southern Scandinavia and beyond. At both Dösjebro and Bunkeflostrand there are other traces of outside contacts in the form of small pieces of pottery. At both locations cord-ornamented pottery has been found in contexts dated to the early half of the Middle Neolithic B (see Svensson 2002 for Dösjebro). At both sites ceramic analysis of the shards has shown they were made in a technique previously not known or used in southern Scandinavia (Stilborg 2005; Brorsson 2008). The use of chamotte as a temper was introduced as a new technique in pottery making in the early Battle Axe culture. These new influences can thus be linked to the palisade enclosures in Scania, indicating that this took place some time before the introduction of the burial custom characteristic of the Battle Axe culture, at least in the western part of Scania. It has been proposed that potters from the Continent brought this new technique to southern Scandinavia (Hulthén r 977:I43ff). We believe that this is in accordance with the evidence from the enclosures, where traces of special groups and their long-distance contacts are seen. Of course, only a small part of the evidence from enclosures has been used in the above interpretation. But their role in social life can also be revealed on a more general level through the architecture of the different enclosures.

The palisade enclosures reveal both complexity and simplicity through their architecture. The architecture was not regulated by the rules that created the stricter form of the older Sarup sites, reflecting a social organization of smaller family groups from the surrounding areas. The complexity in details of the Malmö enclosures, perhaps best seen at Hyllie (Fig. 7), cannot be understood in full when it comes to the motives and reasons behind the flowing, changing, but also symmetrical rhythm of the lines of posts. Narrow passages opening up into wider space and closing up again as you move along indicate special purposes for different parts of the enclosure. Simplicity in architecture, on the other hand, is seen through their large and seemingly open interior spaces, with few or no indications of internal spatial division. As discussed earlier, however, evidence from Hyllie and Dösjebro has revealed such an internal division. The architecture of Hyllie clearly indicates several other such special areas of meaning, which is not immediately the case at Dösjebro. At Bunkeflostrand the sporadic preservation of ditches and postholes at the enclosure gives evidence of a once irregular and in parts complicated structure in architectural 
details (Fig. 3). It is nevertheless not immediately possible to understand and interpret it in detail with regard to display and representation of different social groups and their interests. Perhaps such special interests were not part of the architecture in every enclosure? Bunkeflostrand is perhaps best seen as a large, single room of importance to the surrounding community as a whole, both as an important fishing site and a place where contacts with the outside world took place on a regular basis.

Through their geographically wide contacts and their early contact with new influences, ideas and new material culture, the social groups that manifested their importance at the enclosures formed powerful entities at the local level. Social and cultural change was actually spread through the gates of the enclosures, at least in western Scania. The change was, however, gradual and asymmetrical in relation to homogeneous groups of family or kin. Eventually society changed to what we, through the burials, recognize as the Battle Axe culture. By then the palisade enclosures were no longer a visual part of the landscape. In other areas of southern Scandinavia, such as Bornholm, this culture seems to have been connected to the large settlements. It is there that the earliest evidence of Battle Axe culture influence is found (KempfnerJørgensen \& Watt I 985), and not inside the palisade enclosures. The enclosures on Bornholm, as well as Zealand, seem to be more closely related to older traditions, as seen in the material evidence from the sites and in one case also in the direct location at the site of an older Sarup causewayed enclosure (Kaul et. al. 2002). Thus, the general evidence of the palisade enclosures tells of different strategies in dealing with new influences and negotiating social change at the local level.

\section{LIFE INSIDE A PALISADE ENCLOSURE}

In this article the palisade enclosures of southern Scandinavia have been interpreted as important arenas for forming social relations and cultural change. In their local contexts the palisade enclosures were places of diverse activities, where social relations were formed, expressed and negotiated through space, action and material culture. Different groups of people who manifested themselves in the palisade enclosures gradually changed local society through contact with the outside world.

Eventually the enclosures as arenas for shaping and controlling local society became less powerful as new relations were formed by individuals or as groups of individuals aspiring for power turned their 
back on these traditional sites as places of importance. The decision not to build them anymore must have been a significant one seen as a local event. They were no longer considered relevant to society. This seems to have happened simultaneously over large parts of southern Scandinavia. After c. 2600 to $2500 \mathrm{BC}$ these arenas were no longer built, and no other single buildings of this size or collective effort were erected in southern Scandinavia for a long time to come.

During its time of use the palisade enclosure at Bunkeflostrand was of great importance to society on many levels. The wooden walls enclosed activities that in one sense can be seen as fulfilling important needs in the everyday life of the local community - fishing being one of the more important tasks at the site - but they also enclosed a place where contacts were established with the outside world, which were vital to the forming and changing of social and cultural relations in the area. The significance of the site was marked by erecting the palisades, a clear signal to people in the area and to outside visitors that this place, on the shore of Öresund, was to be respected but not avoided.

\section{Notice}

In September 2009 our dear friend and colleague Ingela Kishonti (1969-2009) passed away. Ingela was an antiquarian at Malmö Heritage where she was engaged in contract archaeology. She was engaged in the Öresund Link project where her focus was on the use of scientific analyses within archaeology. She had an MA in Landscape Archaeology dealing with the formation of cultural deposits from the Bronze Age. We will always remember her as a woman with a warm heart and a big smile.

Kristian Brink ó Ola Magnell

Kristian Brink, Malmö Museer, Box 406, 20124 Malmö, Sweden

Ola Magnell, Institutionen för arkeologi och antikens historia, Lunds universitet, Sandgatan I, 22350 Lund, Sweden

\section{References}

Andersen, N. H. 1.997. The Sarup Enclosures. Sarup vol. 1. Jysk Arkæologisk Selskab. Moesgård. Aarhus.

Andersson, M. 2004. Making place in the landscape. Skannska spår - arkeologi längs Västkustbanan. Riksantikvarieämbetet. Avdelningen för arkeologiska undersökningar. UV Syd. Lund. 
Barrett, J. C. $200 \mathrm{I}$. Agency, the Duality of Structure, and the Problem of the Archaeological Record. In: Hodder, I. (Ed.). Archaeological Theory Today. Pp. 14I-I64. Cambridge: Malden.

Björhem, N. \& Magnusson Staaf, B. 2006. Öresundsförbindelsen och arkeologin. Långhuslandskapet. En studie av bebyggelse och samhälle från stenålder till järnålder. Malmöfynd 8. Malmö: Malmö Kulturmiljö.

Bradley, R. 2005. Ritual and Domestic Life in Prehistoric Europe. London: Routledge.

Brink, K. 2004. The palisade enclosure at Hyllie, SW Scania. Journal of Nordic Archaeological Science 14 (2004). Pp. 35-44.

Brink, K. 2009 . I palissadernas tid. Om stolphål och skärvor och sociala relationer under yngre mellanneolitikum. Malmöfynd nr $2 \mathrm{I}$. Malmö: Malmö Museer.

Brink, K., Grehn, F. \& Kishonti, I. 2008. Arkeologisk slutundersökning 2006. Bunkeflostrand i 5:r. En mellanneolitisk palissad och tre järnäldersgravar. Bunkeflo socken i Malmö stad, Skåne län. Enheten för Arkeologi Rapport 2008:035. Malmö Kulturmiljö. Malmö.

Brink, K. \& Hydén, S. 2006. Citytunnelprojektet. Hyllie vattentorn-delområde 4 och Palissaden-delomräde 5. Rapport över arkeologisk slutundersökning. Rapport nr 42. Malmö Kulturmiljö. Malmö.

Brorsson, T. 2008. Godsanalys av stridsyxekeramik frän Bunkeflostrand, Bunkeflo sn, Malmö. Kontoret för Keramiska Studier. Rapport I6. Vadensjö.

Cardell, A. 2005. Djurhållning och subsistensekonomi. In: Mogren, M. (Ed.). Byarnas bönder. Medeltida sambällsförändring $i$ Västskåne. Skånska spår-arkeologi längs Västkustbanan. Riksantikvarieämbetet. UV Syd. Pp. 278-293. Lund.

Damm, C. 1991. Continuity and Change. An Analysis of Social and Material Pat terns in the Danish Neolithic. Unpubl. PhD diss. Cambridge.

Damm, C. 1993. The Danish Single Grave Culture - Ethnic Migration or Social Construction? Journal of Danish Archaeology. Vol ro, 1991. Pp. I99-204.

Edenmo, R., Larsson, M., Nordqvist, B. \& Olsson, E. 1997. Gropkeramikerna fanns de? Materiell kultur och ideologisk förändring. In: Larsson, M. \& Olsson, E. (Eds.). Regionalt och interregionalt. Stenåldersundersökningar $i$ Syd-och Mellansverige. Riksantikvarieämbetet. Arkeologiska undersökningar. Skrifter nr 23. Pp. $135-213$. Stockholm.

Enghoff, I. B. 1987. Freshwater fishing from a sea-coast settlement - the Ertebölle locus classicus revisited. Journal of Danish Archaeology; Vol 5. Pp. 62-76.

Friman, B. 2006. Arkeologisk shutundersökning. Palissad frän neolitikum. Västra Klagstorp I1:38-1 I:42 och I1:44-II:59. Västra Klagstorp socken i Malmö stad, Skåne län. Enheten för Arkeologi Rapport 2006:021. Malmö Kulturmiljö. Malmö.

Gibson, A. 2002. Behind Wooden Walls: Neolithic Palisaded Enclosures in Europe. BAR International Series IOI3. Oxford: Archaeopress.

Hadevik, C. 2009. Trattbägarkulturen i Malmöområdet. In: Hadevik, C. \& Steineke, M. (Eds.). Spåren i marken. Rapport nr 48. Malmö Kulturmiljö. Malmö.

Giersing, T. 2004. Et mellemneolitisk palisadeanlæag ved Helgeshøj, Østsjælland. Aarboger for Nordisk Oldkyndighed og Historic 200 I. Pp. 7-34.

Hulthén, B. 1977. On Ceramic Technology During the Scanian Neolithic and Bronze Age. Theses and Papers in North-European Archaeology 6. Stockholm: Akademilitteratur.

Jonsson, L. 2003. Diurbenen frän Citytunneln, område 5, palissadanläggning frän Neolitikum samt gropar frän järnalder. Rapport 2003:32. Arkeologiskt Naturvetenskapligt Laboratorium. Göteborgs universitet. 
Karsten, P. 1994. Att kasta yxan isjön. En studie över rituell tradition och förändring utifrån skänska neolitiska offerfynd. Acta Archaeologica Lundensia. Series in $8^{\circ}$, No. 23. Stockholm: Almqvist \& Wiksell.

Kaul, F., Nielsen, F. O. \& Nielsen, P. O. 2002. Vasagård og Rispebjerg. To indhegnede bopladser fra yngre stenalder på Bornholm. Nationalmuseets Arbejdsmark, 2002. Pp. II9-I38.

Kempfner-Jørgensen, L. \& Watt, M. 1985. Settlement Sites with Middle Neolithic Houses at Grødby, Bornholm. Journal of Danish Archaeology. Vol 4, 1985. Pp. 87-го0.

Kristiansen, K. 1991. Prehistoric Migrations-the Case of the Single Grave and Corded Ware Cultures. Journal of Danish Archaeology. Vol 8, I989. Pp. 2 I I-225.

Larsson, L. 1992a. Neolithic Settlement in the Skateholm area, Southern Scania. Meddelanden från Lunds Universitets Historiska Museum I991-92, New Series 9. Pp. 5-43.

Larsson, L. 1992b. Settlement and environment during the Middle Neolithic and Late Neolithic. In: Larsson, L., Callmer, J. \& Stjernquist, B. (Eds.). The Archaeology of the Cultural Landscape. Field work and research in a south Swedish rural region. Acta Archaeologica Lundensia. Series in $4^{\circ}$. No 19. Pp. 91-159. Stockholm: Almqvist \& Wiksell.

Larsson, L. 2004. Of maces and men. Symbols in a landscape of cultural diversity. Journal of Nordic Archaeological Science, Vol i 4. Pp. 7 I -78 .

Larsson, M. 2006. A Tale of a Strange People. The Pitted Ware Culture in Southern Sweden. Kalmar Studies in Archaeology vol 2. Report Series No. 96, University of Lund, Department of Archaeology and Ancient History. Kalmar \& Lund.

Lindholm, P., Olsson, E. \& Runeson, H. 2007. Grop, snöre och kam. In: Gustafsson, P. \& Spång L-G. (Eds.). Stenålderns stationer. Arkeologi i Botniabanans spår. Pp. 20I-235. Stockholm: Riksantikvarieämbetet.

Magnell, O. 2007. Osteologisk analys 2007. Torsk och horn. Osteologisk analys av djurben från en mellanneolitisk palissadanläggning, slutundersökning av Bunkeflostrand i 5: I. Bunkeflo socken i Malmö stad, Skåne län. In: Brink, K., Grehn, F. \& Kishonti, I. 2008. Arkeologisk slutundersökning 2006. Bunkeflostrand I 5:I. En mellanneolitisk palissad och tre järnäldersgravar. Bunkeflo socken i Malmö stad, Skåne län. Enheten för Arkeologi Rapport 2008:035. Malmö Kulturmiljö. Malmö.

Malmer, M.P. 1962.Jungneolithische Studien. Acta Archaeologica Lundensia. Series in $8^{\circ}$. No 2. Lund: Lund University.

Malmer, M. P. 2002. The Neolithic of South Sweden. TRB, GRK and STR. Stockholm; Kungl. Vitterhets historie och antikvitets akademien.

Mésez, M. \& Bartosiewicz, L. 1994. Fish bone preservation and fat content. Offa, Vol 5 r.Pp. 36I-364.

Nicholson, R. 1992a. An assessment of the value of bone density measurements to archaeoichthyological studies. International Journal of Osteoarchaeology, Vol 2. Pp. I39-I 54 .

Nicholson, R. r.992b. Bone survival: the effects of sedimentary abrasion and trampling on fresh and cooked bone. International Journal of Osteoarchaeology, Vol 2. Pp. 79-90.

Nielsen, P. O. 2004. Causewayed camps, palisade enclosures and central settlements of the Middle Neolithic in Denmark. Journal of Nordic Archaeological Science, Vol I4. Pp. 19-33.

Nilsson, L. 2006. Öresundsförbindelsen och arkeologin. Diur och människor längs vägen. Malmöfynd 9. Malmö Kulturmiljö. Malmö. 
Nyegaard, G. I 985 . Faunalevn fra yngre stenalder på øerne syd for Fyn. In: Skaarup, J. (Ed.). Yngre stenalder på øerne syd for Fyn. Pp. 426-457. Rudkøbing: Langelands museum.

O'Connor, T. 2000. The Archaeology of Animal Bones. College Station: Texas A\&M University Press.

Olivier, L. 1999. Duration, memory and the nature of the archaeological record. In: Gustafsson, A. \& Karlsson, H. (Eds.). Glyfer och arkeologiska rum - en vänbok till Jarl Nordbladh. Pp. 529-535. Gothenburg: Gothenburg university.

Parker Pearson, M. \& Richards, C. r 994. Ordering the World: Perceptions of Architecture, Space and Time. In: Parker Pearson, M. \& Richards, C. (Eds.). Architecture and Order. Approaches to Social Space. Pp. I-37. London: Routledge.

Rostoványi, v. A. 2007. Öresundsförbindelsen och arkeologin. Stenålderslandskapet. Inte bara jägare och bönder. Malmöfynd I . Malmö Kulturmiljö. Malmö.

Rudebeck, E. 1986. Ängdala. Flintgruvor från yngre stenåldern, S. Sallerup. Utgräuningar 1977-81. Rapport nr I. Malmö museer. Malmö.

Sarnäs, P. \& Nord Paulsson, J. 200 т. Öresundsförbindelsen. Skjutbanorna r B ó Elinelund $2 A-B$. Rapport över arkeologisk slutundersökning. Rapport $\mathrm{nr} 9$. Malmö Kulturmiljö. Malmö.

Skak-Nielsen, N.V. 2006. The Genesis of the Battle Axe Culture. On Klaus Ebbesen's doctoral thesis. A critique and an alternative conclusion. Fornuännen 2006/4. Pp. 274-277.

Stilborg, O. 2005. Stridsyxekeramik i Sydsverige. KFL Rapport 05/I02I. Keramiska Forskningslaboratoriet. Kvartärgeologiska avdelningen. Lund: Lunds universitet.

Strömberg, M. 1988. Exchange Systems between Battle-axe Groups? In: Hårdh, B., Larsson, L., Olausson, D. \& Petré, R. (Eds.). Trade and Exchange in Prehistory. Studies in Honour of Berta Stjernquist. Acta Archaeologica Lundensia. Series in $8^{\circ}$. No 16. Pp. 7r-8 r. Stockholm: Almqvist \& Wiksell.

Svensson, M. I99I. A Palisade Enclosure in South-West Scania - a Site from the Battle-Axe Culture. In: Jennbert, K., Larsson, L., Petré, R. \& WyszomirskaWerbart, B. (Eds.). Regions and Reflections. In Honour of Märta Strömberg. Acta Archaeologica Lundensia. Series in $8^{\circ}$ No. 20. Pp. 97-109. Stockholm: Almquist \& Wiksell.

Svensson, M. 2002. Palisade Enclosures - The Second Generation of Enclosed Sites in the Neolithic of Northern Europe. In: Gibson, A. (Ed.). Bebind Wooden Walls: Neolithic Palisaded Enclosures in Europe. BAR International Series ror 3. Pp. 28-58. Oxford: Archaeopress.

Svensson, M., Pihl, H. \& Andersson, M. 20or. Palissadkomplexet i Dösjebro. Seminariegräuning vårterminen 2000. Arkeologisk undersökning. UV Syd Rapport 200I:I. Riksantikvarieämbetet, Avdelningen för arkeologiska undersökningar. Lund.

Tauber, H. I986. C I 4 dateringer af Enkeltgravskultur og Grubekeramisk kultur i Danmark. In: Adamsen, C. \& Ebbesen, K. (Eds.). Stridsøksetid i Sydskandinavien. Arkæologiske skrifter 1. Pp. 196-204. Copenhagen: University of Copenhagen.

Thörn, R. 2007. Öresundsförbindelsen och arkeologin. Det ideologiska landskapet. Malmöfynd 12. Malmö Kulturmiljö. Malmö.

Wild, C. J. \& Nichol, R. K. 1983. Estimation of the original number of individuals from paired bone counts using estimators of the Krantz type. Journal of Field Archaeology 10. Pp. 337-344. 
